\title{
Durability properties of concrete made with polyethylene terepthalate and polypropylene as replacement of fine aggregate
}

\author{
Suram Raju ${ }^{1}$,Vegiraju Naresh Kumar $\operatorname{Varma}^{2}$ and $T$. Srinivas ${ }^{3}$ \\ ${ }^{1} \mathrm{M}$. Tech Scholar, GRIET, Hyderabad, India \\ ${ }^{2}$ Assistant Professor, GRIET, Hyderabad, India \\ ${ }^{3}$ Professor, GRIET, Hyderabad, India.
}

\begin{abstract}
Polyethylene Terephthalate (PET) and Polypropylene (PP) is mostly used materials for making items like water bottles, food containers and many other plastic products in all fields of life. Due to the scarcity of natural aggregates for making concrete, it is required to go for alternative material, this type of plastic is one of the materials for replacement of fine aggregate in concrete. An objective of this paper is to study the feasibility of this recycled PET and PP plastic waste to be used as a building material in manufacturing of concrete which is replaced in fine aggregate. Polyethylene Terephthalate and Polypropylene is used in various percentages like $5 \%, 10 \%, 15 \%$ and also various tests like workability and compressive strength, Sorptivity, water absorption, acid attack and sulphate attack tests are conducted. From the results the PP shows good workability but low compressive strength than PET. From the durability point of view, the concrete made with PET and PP have given better results compared to conventional concrete of M30 grade. In PET and PP concrete, PET resists the acid, sulphate and water over the long period much better than the PP. So, PET can be replaced up to $10 \%$ in fine aggregate, whereas PP is allowed up to $5 \%$ replacement of fine aggregate.
\end{abstract}

\section{Introduction}

Plastic of its nature would take several years for decomposition. In today's situation production of plastic increases even after banning its usage. Rapidly growing nations like india, nearly 60 million tons of waste is disposed annually. The PET and PP disposal is complex issue causes effects on the environment and surrounding due to inceration and degradation. Researchers studied on eco-friendly waste plastic disposal. The utilization of plastic in the various fields like architectural and construction industry. The commonly used plastics are this plastic. The plastic maintenance is very easy not require any technology. The PET $\mathrm{a}^{*}$ nd PP can be used polyethylene terephthalate as substituent for sand in concrete with $5 \%, 10 \%, 15 \%$. It influences the properties of concrete. The results shows that the reduction in unit weight by different percentages. D Ambika2020[] investigated on crushed pet bottles in concrete as fine aggregate it improves strength of concrete. Pet and PP as fine aggregate to enhance the properties of concrete as light weight and efficient concreteThe spécimens casted and cured for 28 days strength. From the results compressive strength increases $10 \%$.AO Dawood2020[] studied on durability properties of concrete. Different percentages of PET particles used in
Polyethylene terephthalate and polypropylene In construction industry the major problem is the lack of natural aggregates. The usage of waste plastic in construction materials, is an effective utilised mehod. Polyethylene and polypropylene are available plastics to replace in the construction materials like fine aggregate and coarse aggregate.

The ideology of this paper is to know what extent can be used

efficiently with proper engineering works. Ibrahim almeshal2020[] investigate the using

concrete as Fineaggregate.Specimens are tested for 7 , 14, and 28 days. From this investigation PET ratios increases water absorption rate increases. PET particles positively effects the concrete as the replacement is less than $15 \%$. Vasanti P2020[] investigated on nonbiodegradable waste, $\mathrm{M}$ - sand with fine aggregate partially replaced individually. The results shows that compressive strength and flexural strength increases with waste materials than the conventional concrete. $\mathrm{R}$ kehan2019[] In this study, Polypropylene as fine aggregate partially in concrete mix design. Prepared 6 different mixes with polypropylene replacements from

*Corresponding Author: srinu.tummala@gmail.com 
0.5 to $3.0 \%$. As a result shows compressive strength decreases as polypropylene content increases. Maqbool2019[] studied on using the the replacement of aggregate in Portland cement as waste PET bottles. Different percentages of waste bottle fibre is used in concrete mix. The spécimens casted and cured for 28 days strength. From the results compressive strength increases $10 \%$.

\section{Experimental investigation}

The test to be conducted here on durability properties of concrete are
1. Sorptivity test
2. Water absorption test
3. Acid attack (ADF)
4. Sulphate attack test

\subsubsection{Sorptivity test}

This test conducted on M30 grade of concrete with PET and PP individually. The test is to indicating the absorption rate in concrete. The specimen is sealed all sides excepting the water contacting area. Sorptivity coefficient values obtained by

$$
\begin{aligned}
& \quad \mathrm{I}=\frac{M}{A p} \\
& \mathrm{I}=\text { Sorptivity absorption rate } \\
& \mathrm{M}=\text { Mass of specimen } \\
& \mathrm{A}=\text { Area of contact area } \\
& \mathrm{P}=\text { density of water }
\end{aligned}
$$

Sorptivity coefficient $(\mathrm{S})=\frac{I}{\sqrt{t}}\left(\frac{\mathrm{mm}}{\sqrt{\mathrm{min}}}\right)$

Table 1. Sorptivity values

\begin{tabular}{|l|l|l|l|l|}
\hline S.NO & Time in min & \multicolumn{3}{|c|}{ Sorptivity value } \\
\hline & & C & PET & PP \\
\hline 1 & 15 & 0.15 & 0.19 & 0.23 \\
\hline 2 & 30 & 0.17 & 0.2 & 0.26 \\
\hline 3 & 60 & 0.19 & 0.22 & 0.29 \\
\hline 4 & 120 & 0.20 & 0.25 & 0.30 \\
\hline 5 & 240 & 0.13 & 0.23 & 0.24 \\
\hline 6 & 1440 & 0.1 & 0.18 & 0.21 \\
\hline
\end{tabular}

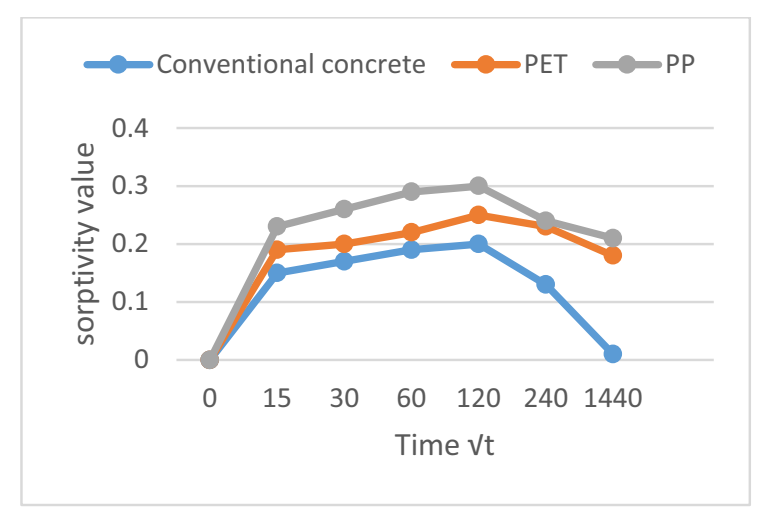

Fig 1. Shows Sorptivity values with time $\sqrt{ } \mathrm{t}$

\subsubsection{Water absorption}

This test is to know the water absorption rate of concrete when it is fully submerged in water. The absorption rate is calculated by

$$
\begin{gathered}
\quad=\frac{W 2-W 1}{W 1} \\
\mathrm{~W}_{1}=\text { Dry weight of cube } \\
\mathrm{W}_{2}=\text { wet weight of cube }
\end{gathered}
$$

From the above relation get the $\%$ of water absorption

Table 2. \% of Water absorption

\begin{tabular}{|l|l|l|l|l|}
\hline S.NO & Time in min & \multicolumn{4}{|l|}{ \% Water absorption } \\
\hline & & C & PET & PP \\
\hline 1 & 15 & 2.4 & 2.6 & 2.9 \\
\hline 2 & 30 & 2.5 & 2.8 & 3.2 \\
\hline 3 & 60 & 2.8 & 3.2 & 3.4 \\
\hline 4 & 120 & 3.0 & 3.4 & 3.6 \\
\hline 5 & 240 & 3.2 & 3.5 & 3.8 \\
\hline 6 & 1440 & 2.8 & 3.2 & 3.5 \\
\hline
\end{tabular}

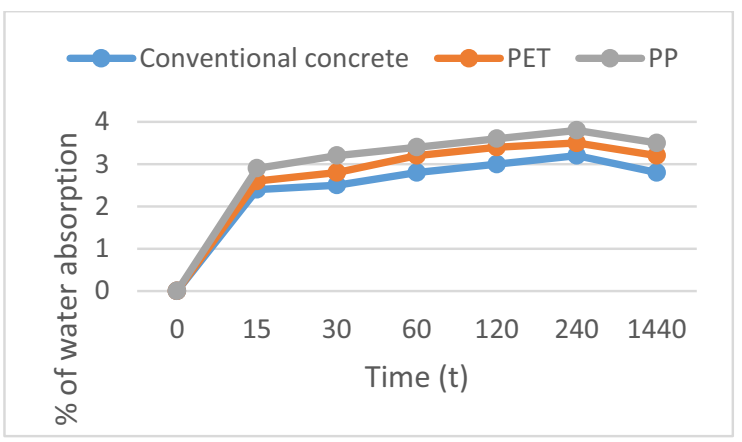

Fig 2. Shows variation of water absorption with time

\subsubsection{Acid attack test}

Concrete structures are attack by acids and losses its strength to its severity, then reduces the life span of the structure. After 28 days curing period cubes immersed in chemical with $5 \%$ HCL up to 15,30 and 45 days. 
Table 3. The $\%$ loss of compressive strength of M30 grade of concrete in 5\% HCL solution.

\begin{tabular}{|l|l|l|l|l|}
\hline & $\begin{array}{l}\text { Strength } \\
\text { Before } \\
\text { immersion }\end{array}$ & \multicolumn{3}{|l|}{$\begin{array}{l}\text { Strength After } \\
\text { immersion }\end{array}$} \\
\hline & & 15 & 30 & 45 \\
\hline $\begin{array}{l}\text { Normal } \\
\text { concrete }\end{array}$ & 38.7 & 38.2 & 37.5 & 36.9 \\
\hline $\begin{array}{l}\text { \% of } \\
\text { strength loss }\end{array}$ & & 1.29 & 3.1 & 4.65 \\
\hline PET & 38.2 & 37.9 & 37.2 & 36.8 \\
\hline $\begin{array}{l}\text { \% of } \\
\text { strength loss }\end{array}$ & & 0.91 & 2.745 & 3.94 \\
\hline PP & 38.3 & 38.1 & 37.3 & 36.7 \\
\hline $\begin{array}{l}\text { \% of } \\
\text { strength loss }\end{array}$ & & 0.52 & 2.61 & 4.17 \\
\hline
\end{tabular}

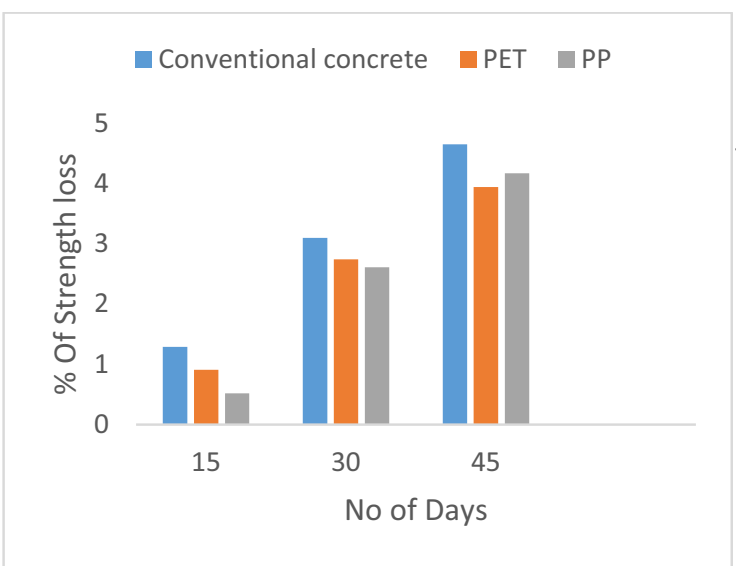

Fig 3. Shows variation of $\%$ of strength loss with no of days of immersion

\subsection{3 (a) Acid Durability Factors (ADF)}

Acid durability factor $=\frac{\text { Relative strength } \times N}{M}$

Relative strength $=100-\%$ of compressive strength loss $\mathrm{N}=$ number of days of Immersion in acid

$\mathrm{M}=$ number of days test to be conducted

Table4. Acid durability factor of M30 grade concrete in 5\% HCL solution.

\begin{tabular}{|l|l|l|l|l|}
\hline S.NO & $\begin{array}{l}\text { Days of } \\
\text { Exposer }\end{array}$ & \multicolumn{2}{|c|}{ ADF } \\
\hline & & C & PET & PP \\
\hline 1 & 15 & 32.96 & 33.03 & 33.16 \\
\hline 2 & 30 & 64.6 & 64.84 & 64.92 \\
\hline 3 & 45 & 95.35 & 96.86 & 95.83 \\
\hline
\end{tabular}

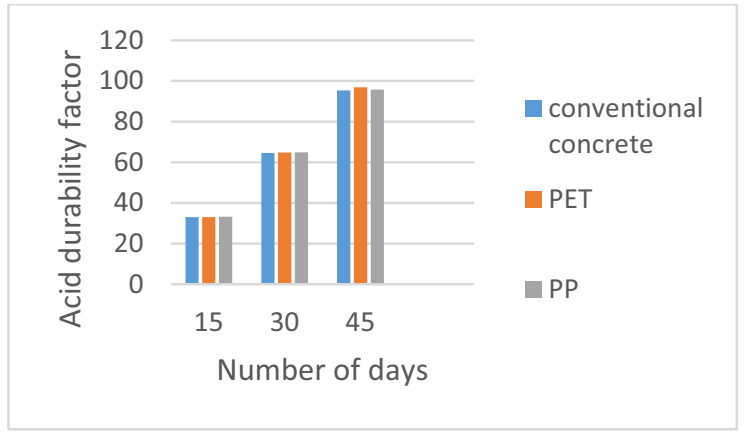

Fig 4. Shows acid durability factor with no of days

\subsubsection{Sulphate attack}

Cubes immersed in 5\% sodium sulphate up to 15,30 and 45 days

Table 5 : The $\%$ loss of strength of M30 grade concrete with $5 \%$ sodium sulphate.

\begin{tabular}{|l|l|l|l|l|}
\hline & $\begin{array}{l}\text { Strength } \\
\text { Before } \\
\text { immersion }\end{array}$ & \multicolumn{3}{|l|}{$\begin{array}{l}\text { Strength After } \\
\text { immersion }\end{array}$} \\
\hline & & 15 & 30 & 45 \\
\hline $\begin{array}{l}\text { Normal } \\
\text { concrete }\end{array}$ & 38.7 & 38.5 & 38.3 & 37.9 \\
\hline $\begin{array}{l}\text { \% of } \\
\text { strength loss }\end{array}$ & & 0.51 & 1.03 & 2.07 \\
\hline PET & 38.2 & 38 & 37.9 & 37.5 \\
\hline $\begin{array}{l}\text { \% of } \\
\text { strength loss }\end{array}$ & & 0.52 & 0.78 & 1.83 \\
\hline PP & 38.3 & 37.9 & 37.9 & 37.4 \\
\hline $\begin{array}{l}\text { \% of } \\
\text { strength loss }\end{array}$ & & 1.04 & 1.31 & 2.36 \\
\hline
\end{tabular}

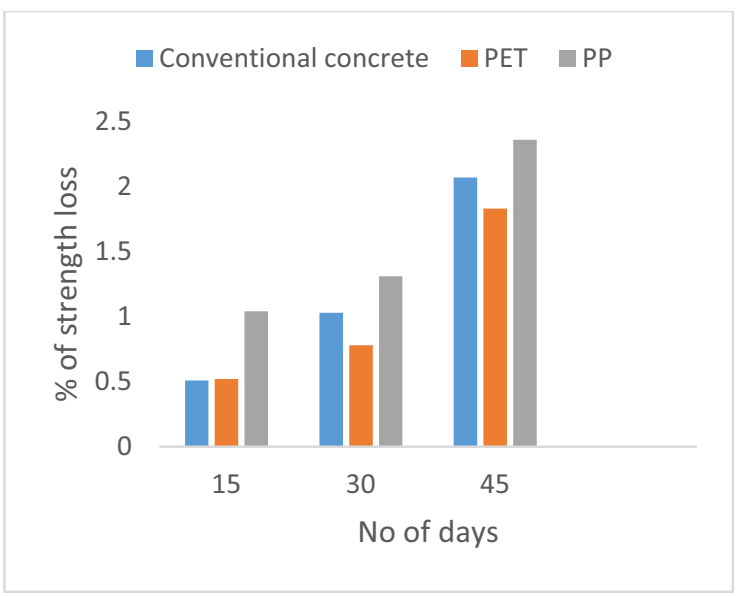

Fig 5. Shows variation of $\%$ of strength loss with no of days of immersion 


\section{Conclusions}

The durability properties such as; Sorptivity and water absorption of concrete made with PET and PP compared to conventional concrete shows more absorption rate than conventional concrete but these two are within the limits only as per standards. In acid and sulphate tests, the concrete made with PET and PP shows better results as compared to conventional concrete, in which PET is much better than PP. In PET and PP concrete, PET resists acids like $\mathrm{HCL}, \mathrm{H}_{2} \mathrm{SO}_{4}$ and sulphates like $\mathrm{MgSO}_{4}, \mathrm{NaSO}_{4}$ and water over the long period much better than the PP. So, PET can be replaced up to $10 \%$ in fine aggregate, whereas PP is allowed up to $5 \%$ replacement of fine aggregate.

\section{References}

1. Ambika, Devarajan, Marimuthu Sabitha, and Sureshram Pravinraj.(2019).

2. Maqbool, Younus, et al IJARIIT( 2019): 52429.(2019)

3. Almeshal, Ibrahim, et al. "JMRT 9.3: 46314643. (2020)

4. Vasanthi, P., et al. Materials Today: Proc 39 459-466. (2021)

5. Araghi, H. Janfeshan, et al 77: 461-471. (2015)

6. Nikbin, Iman M., et al. Journal of Cleaner Prod. 126 : 108-117.( 2016)

7. Law, A. S. L., et al. Vol. 357. No. 1. IOP Publishing, (2019)

8. Hama, Sheelan Mahmoud. 1-15. (2020)

9. Karthik Rao, R., Bobba, P.B., Suresh Kumar, T., Kosaraju, S. Materials Today: Proceedings, 26, pp. 3085-3089, 2019

10. T.Srinivas and M. Abinay Raj, Int. J. of Eng.and Adv. Tech. (IJEAT), ISSN: $2249-$ 8958, Volume-8 Issue-6 (2019)

11. K. satyanarayana, S. K. Singh, T. Buddi, K. Anil and A. U1 Haq, Advances in Materials and Processing Technologies, 6(2), 365 (2020)

12. T.srinivas and P. Manoj Anand, Int. J. of Innov. Tech. and Explor. Eng.g (IJITEE), ISSN: 2278-3075, Volume-8 Issue-12 (2019)

13. T.Srinivas and G. Sukesh Reddy, Int. J. of Eng.and Adv. Tech. (IJEAT), ISSN: $2249-$ 8958, Volume-9 Issue-1 (2019)

14. T.Srinivas and R. N. Koushik, Int. J. of Innov. Tech. and Explor. Eng.g (IJITEE), ISSN: 2278-3075, Volume-8 Issue-12 (2019), PP 112-117.

15. K. Sai Gopi, Dr. T. Srinivas and S. P. Raju V, E3S Web of Conferences ICMED 184, 01084GRIET, 28-29 February, https://doi.org/10.1051/e3sconf/20201840110 84(2020)

16. Jagannadha Kumar, M.V., Jagannadha Rao, K., Dean Kumar, B., Srinivasa Reddy, V., Int. J. of Civil Eng. and Tech., 9(7), pp. 1133-1141
(2018)

17. Ganta, J.K., Seshagiri Rao, M.V., Mousavi, S.S., Srinivasa Reddy, V., Bhojaraju, C., Structures 28, pp. 956-972 (2020)

18. Naidu, K.S.S.T., Rao, M.V.S., Reddy, V.S., Int. J. of Innov. Tech. and Explor. Eng.g (IJITEE), 8(9 Special Issue 2), pp. 641-642 (2019)

19. Chandana Priya, C., Seshagiri Rao, M.V., Srinivasa Reddy, V., Int. J. of Civil Eng. and Tech., 9(11), pp. 2218-2225 (2018)

20. Satya Sai Trimurty Naidu, K., Seshagiri Rao, M.V., Srinivasa Reddy, V., Int. J. of Civil Eng. and Tech., 9(11), pp. 2383-2393 (2018)

21. Supriya, Y., Srinivasa Reddy, V., Seshagiri Rao, M.V., Shrihari, S., Int. J. of Rec. Tech. and Engi., 8(3), pp. 5381-5385 (2019)

22. Kotkunde, N., Krishna, G., Shenoy, S.K., Gupta, A.K., Singh, S.K. International Journal of Material Forming, 10 (2), pp. 255-266 (2017)

23. Raju, N.A., Suresh Kumar, T. International Journal of Innovative Technology and Exploring Engineering, 8(11), pp. 3860-3864, 2019

24. Govardhan, D., Kumar, A.C.S., Murti, K.G.K., Madhusudhan Reddy, G. Materials and Design, 36, pp. 206-214. (2012)

25. Kumar, P., Singhal, A., Mehta, S., Mittal, A. Journal of Real-Time Image Processing, 11 (1), pp. 93-109. (2016)

26. Raghunadha Reddy, T., Vishnu Vardhan, B., Vijayapal Reddy, P. International Journal of Applied Engineering Research, 11 (5), pp. 3092-3102 (2016)

27. Hussaini, S.M., Krishna, G., Gupta, A.K., Singh, S.K. Journal of Manufacturing Processes, 18, pp. 151-158 (2015) 